EDITORIAL

\title{
Travel, Pilgrimage and Health Hazards
}

Today more people are travelling than ever before. Travel used to be a leisure which could only be afforded by a few. However, with time passing by, more people are travelling, forming it an imperative part of their lives. Travelling enriches the individual with new experiences and outlook towards life. The rise in travel has been helped out by better means and mode of transportation, which has been further instilled by the fad of globalization. With invention of newer modes of transportation such as trains, aircraft, ships and vehicles, the means of travel have increased considerably compared to past. The travellers have now the luxury to choose what suits their budget and requirements. Air travel particularly has become such a convenient and accessible form of transportation that each year, an estimated one billion people travel on domestic and international airlines. With the surge of globalization, many companies and corporate are spreading their operation across the boundaries, requiring their employees to travel frequently for work purposes. Paralleling the surge of travelling, there is a growing trend towards cultural tourism and pilgrimages.

With more people travelling, health care professionals should become more familiar with some of the unique health issues associated with travel and pilgrimage. ${ }^{1}$ Travel has some unique safety and health issues, especially for the young and the elderly. Physicians need to be aware of the health issues related to travelling, identify people at risk for health problems during travel, and provide appropriate anticipatory guidance. Many guidelines have been developed to help inform physicians about some of the health issues of people travelling. ${ }^{2}$ These guidelines are to provide information on the risks of travel to people, determine which preexisting health conditions may be complicated by a particular mode of travel, and offer preventative measures that can minimize potential risks to people during the travel. For example, people travelling by air may need to be informed about potential risks during flight like, transmission of infectious diseases, cardiopulmonary diseases, thromboembolic events, otitis media, flight seizures, etc. Specifically, people with type 1 diabetes many need special advice on managing diabetes during travel. Though flight attendants are trained in basic first aid and cardiopulmonary resuscitation, medical situations may arise on aircraft that may demand assistance from a trained health care provider. Physicians should be aware that if they volunteer to assist on an aircraft, they are protected from liability by the 'Good Samaritan' provision of the Airline Passenger Safety Act.

Religious tourism or faith tourism is a form of tourism, where people travel individually or in groups for pilgrimage, missionary, or leisure purposes. ${ }^{3}$ Though religious tourism has been existing since ages, there has been a pari-passu surge in this type of tourism as well. Modern religious tourists are more able to visit holy cities and holy sites around the world. The world's largest form of mass religious tourism takes place at the annual Hajj pilgrimage in Makkah, Saudi Arabia. The annual Hajj is one of the greatest assemblies of humankind on earth. ${ }^{2}$ Each year, three million Muslims attend the Hajj in Makkah. Apart from Kabba in Makkah, the other most famous holy sites for religious tourism are Kumbh Mela at Varanasi, Bramha temple at Pushkar in Rajasthan, Church of the Nativity in Bethlehem, and the Western Wall in the old city of Jerusalem.

The Holy Cave of Shri Amarnathji, about $141 \mathrm{~km}$ (88 $\mathrm{mi}$ ) from Srinagar, is situated at an altitude of about 13,500 feet $(4,000 \mathrm{~m})$ above sea level, atop South Kashmir Himalayas. ${ }^{4}$ The cave is surrounded by snowy mountains; itself being covered with snow most time of 
the year, except for a short period of time in summer when it is open for pilgrims. The shrine is considered to be one of the holiest shrines in Hinduism. ${ }^{5}$ The pilgrims taking Pahalgam Route have to trek a distance of $32 \mathrm{~km}$ from Chandanwari and those taking Baltal route have to hike a distance of $14 \mathrm{Km}$ to reach the Holy Shrine. An annual pilgrimage is made to the Amarnath Ji cave by lakhs (hundreds of thousands) of Hindu devotees on challenging mountainous terrain to see an ice stalagmite formed inside the cave. The high altitude trek to the Holy Cave involves exposure to extreme cold, low humidity, increased ultraviolet radiations and reduced air pressure. The oxygen level in the air is very low due to which many Yatris face respiratory and other related medical problems. Last year as many as 6,21,145 pilgrims undertook the Amarnathji Yatra in 2012 which saw 93 casualties. ${ }^{6}$ The number of so many causalities, though lower than 106 casualties of 2011 when a total of 6,35,611 pilgrims undertook the Yatra, highlights the health hazards and risks faced by Yatris.

In this issue of the Journal, there is a study by Yatoo, et al $^{7}$ about the pattern and outcome of illness in Yatris attending SKIMS during Amarnathji Yatra. This prospective study was carried during a 45-day Yatra period in which all the Yatris referred to SKIMS were studied. AMI was the main diagnosis at arrival (16.5\%) followed by polytrauma (15.3\%), head injury (11.8\%), high altitude pulmonary edema (HAPE) (10.6\%); gastroenteritis $(10.6 \%)$, diabetes $(10.6 \%)$, COPD (7.1\%), stroke (5.9\%), poison(g (3.5\%), and others $(8.2 \%)$. Of the 85 admitted patients, five patients expired with a mortality of $5.9 \%$. Majority of the deaths were attributed to cardiovascular disease (AMI or stroke); $80 \%$ patients who died in the hospital were aged 65 years. The main conclusion of the study was that Yatris attending Amrnathji yatra face many health related challenges, and a pre-yatra checkup of all yatris should be made mandatory. Though this pilot study was of short duration and limited to patients referred to one hospital, it gives a good reflection of pattern of illnesses during Amarnathji yatra. It displays the demographic characteristics of the pilgrims and shows that elderly Yatris have higher morbidity and mortality, particularly those aged 65 years or older. Two most common co-morbidities encountered at arrival to the hospital were coronary heart disease and diabetes.

The annual Amrnathji Yatra is the biggest congregation of pilgrims in Kashmir Valley. Each year, lakhs of Hindu devotees attend the Yatra; majority of whom usually come from outside Kashmir. Though most of devotees come by road, a good number of them arrive by air as well. This year the Amarnathji yatra is likely to commence from 28th June and expected to conclude on 21st August 2013. ${ }^{8}$ Those planning Yatra need to be aware of health hazards of the yatra, particularly those coming up because of non-acclimatization, lack of proper clothing and footwear, religious practices or traditions, and individual profile of Yatris. Any person, who undertakes a trek in the high altitude area like Amarnathji cave, is required to necessarily undergo acclimatization for several days. Those undertaking the Yatra are un-acclimatized and rush to complete their Yatra within a day, as a result some of whom fail to recover from high altitude sickness (HAPE) and lose their lives. Besides, a large number of pilgrims do not carry adequate/appropriate warm clothing and footwear, are susceptible to falling ill and those who already have serious medical problems like diabetes, cardiovascular disease or chronic obstructive lung disease are more susceptible to medical breakdown. Another reason contributing to serious medical problems is the insistence of devotees to take an ice cold water bath in the morning and then commence their trek with an empty stomach. To overcome extreme cold and exhaustion, some Yatris consume alcohol after visiting the Holy cave which may worsen their medical condition. Profiling of the Yatris reveals that a good number of them comprises of elderly, adolescents and people who are already suffering from ailments. Understandably, they are at high risk, and prone to losing life during the Yatra which involves climbing in a high Altitude difficult area and sudden changes in weather conditions. Though SASB (Shri Amarnathji Shrine Board, the organisation that conducts the Yatra) has been issuing health advisories from time to time that contain Do's and Don't's to be followed by the Yatris, the mortality associated with the yatra seems to be on a rise.

Taking note of certain press reports about the mortality of pilgrims visiting the Holy cave, the Supreme Court of India constituted a special high powered committee to, inter alia, suggest measures for upgrading the healthcare infrastructure in the Yatra area. The said committee, in its report, has made many recommendations dealing with different aspects of healthcare facilities to be provided to the Yatris during Yatra 2013, One of the recommendations of the committee is that, while seeking registration for the pilgrimage, all Yatris should furnish Compulsory Health Certificate in the prescribed format as shown at the end of this article. Another recommendation is that no one 
below the age of 13 years or above the age of 75 years, and no lady with 6 week's pregnancy should be allowed to undertake Yatra. The committee issued specific guidelines for doctors or medical Institutions authorized to issue compulsory health certificate. However, devotees may be still able to get the compulsory health certificates by providing false information about their past medical conditions. Therefore, there is need of education and helath awareness in potential Yatris. They should understand that any mode of travelling with people requires preparation and an awareness of potential safety and health issues. Specific advice should be given to people planning to take Yatra in order to minimise the associated health risks. It would be better if a letter were offered to families travelling with people with known health problems, detailing their medical condition, any need for medication and supplies.

\section{Preventive health measures during the Yatra}

There should be a Yatra preventive health committee that oversees all public health and preventative matters during the Yatra. A large number of public health officers should regulate ports of entry for all pilgrims to ensure compliance with the health requirements. Public health teams should be located at various areas of the Yatra, including some mobile teams. At each entry route, i.e, Pahalgam and Baltal, there should be special clinical examination rooms and a large holding area which is dedicated to assess arriving pilgrims, check their immunisation status, and administer the recommended prophylactic medicines. The public health teams at the entry points as well en route should report a unified command centre on all health issues using electronic and manual surveillance systems. Apart from risk of HAPE in non-acclimatized yatris, two other conditions that should receive special focus are respiratory tract infections and food-borne gastrointestinal diseases. It is recommended that pilgrims continue to practice proper hand hygiene, protective behaviours and cough etiquette to further decrease the occurrence of respiratory diseases. Diarrhoeal illnesses during Yatra are a potential health hazard. Many factors may contribute to this problem including: inadequate standards of food hygiene, shortage of water, the presence asymptomatic carriers of pathogenic bacteria, and the preparation of large numbers of meals poorly stored by pilgrims. In the study by Yatoo et al, diarrhoeal diseases constituted $10.6 \%$ of the hospitalized Yatris. Whereas, in a similar study on Hajj pilgrims, diarrhoea was the third most common cause $(6.7 \%)$ of hospitalisation. ${ }^{9}$ As a precautionary measure the pilgrims should not allowed to bring fresh food from outside. Only properly canned or sealed food or food stored in containers with easy access for inspection should be allowed in. All pilgrims be vaccinated against seasonal influenza. Keeping in view that many unknown cases of diabetes where detected during Yatra, it may be worthwhile to check HbA1c of each Yatri before travel. The suggestion by Yatoo et $\mathrm{al}^{7}$ i.e., limiting the number of yatris to the facilities available is worth considering to avoid overcrowding, mass moment, and the related health hazards.

\section{Dr. Shariq R. Masoodi M.D., D.M., F.A.C.P Executive Editor}

\section{References}

1. Cossar JH, Reid D. Health hazards of international travel. World Health Stat Q 1989;42(2):61-9.

2. Al-Tawfiq JA, Memish ZA. The Hajj: updated health hazards and current recommendations for 2012. Euro Surveill 2012;17(41):pii $=20295$. Available online: http://www.eurosurveillance. org/ViewArticle.aspx?ArticleId =20295

3. http://en.wikipedia.org/wiki/Religious_tourism (Last accessed 30 December 2012)

4. http://en.wikipedia.org/wiki/Amarnath_Temple (Last accessed 30 December 2012)

5. "The pilgrimage to Amarnath Ji". BBC News. 6 August 2002. Retrieved 5 May 2012.

6. http://www.greaterkashmir.com/news/2012/ Aug/15/centre-to-upgrade-amarnath-yatrafacilities-45.asp (Last accessed, 30 December 2012).

7. Yatoo GH, Aubid M, Masoodi SR, Mushtaq S, Khan AS, Jan FA. Profile of patients attending SKIMS Srinagar during 2011 Amarnathji Yatra. Journal of Medical Sciences 2012;15(2):170-173.

8. http://www.shriAmarnath Jijishrine.com/, last accessed on 20 April 2013]

9. Al-Ghamdi SM, Akbar HO, Qari YA, Fathaldin OA, Al-Rashed RS. Pattern of admission to hospitals during muslim pilgrimage (Hajj). Saudi Med J 2003;24(10): 1073-6. 


\section{COMPULSORY HEALTH CERTIFICATE FOR SHRI AMARNATHJI YATRA 2013}

\section{PART A:}

(TO BE FILLED BY APPLICANT)

$$
\begin{aligned}
& \text { Affix cross } \\
& \text { signed } \\
& \text { (by Yatri) } \\
& \text { recent } \\
& \text { photograph }
\end{aligned}
$$

1. Name $\mathrm{S} / \mathrm{O} ; \mathrm{D} / \mathrm{O} ; \mathrm{W} / \mathrm{O}$

Address

2. Date of Birth Identification mark: Blood Group:

3. DECLARATION: Have you suffered from or have history of any of the following:
a) Breathlessness
$\square$ Yes
$\square$ No
b) Diabetes
$\square$ Yes
$\square$ No
c) Respiratory/ lung ailment $\square$ Yes
$\square \quad$ No
d) High Blood pressure
$\square$ Yes
$\square$ No
e) Blood disorder
$\square$ Yes
$\square$ No
f) Asthma
$\square$ Yes
$\square$ No
g) Bleeding tendencies
$\square$ Yes
$\square \quad$ No
h) Epilepsy
$\square$ Yes
$\square$ No
i) Heart ailment
$\square$ Yes
$\square$ No
i) Nervous breakdown
$\square$ Yes
$\square$ No
k) Joint Pains
$\square$ Yes
$\square$ No
I) High altitude/mountain sickness $\square$ Yes
$\square$ No
m) Discharge from ear
$\square$ Yes
$\square \quad$ No
n) History of stroke/ paralysis
$\square$ Yes
$\square$ No
o) Are you a smoker
$\square$ Yes $\square$ No
p) Are you pregnant:
$\square$ Yes
$\square$ No

q) History of Heart Attack; if yes, please specify

r) History of sudden death in family members; if yes, please specify

s) Any major injury in the past; if yes, please specify

t) Any other ailment; if yes, please specify

u) History of surgery; if yes, please specify

v) Are you undergoing under any medication; if yes, please specify

w) Are you allergic to drugs, foods and chemicals; if yes, please specify

4. I hereby declare that the particulars given above are true to the best of my knowledge and belief, and nothing has been concealed.

Date

Signature/ thumb impression of the Applicant)

\section{PART B: (TO BE FILLED BY AUTHORISED MEDICAL AUTHORITY)}

On the basis of information furnished by the applicant, detailed examination and the necessary investigations, it is certified that $\mathrm{Mr} / \mathrm{Ms} / \mathrm{Mrs}$ is fit to undertake the journey to the Shri Amarnathii Holy Cave Shrine.

Details of any specific test conducted before issuing the certificate:

Name of the Doctor

Designation:

Date of issue:
Signature and seal of Authorized Medical Authority

$\mathrm{MCl}$ / State Medical Council Registration No: 